\title{
Ideas in Motion in Baghdad and Beyond
}

\author{
Philosophical and Theological Exchanges \\ between Christians and Muslims in the Third/Ninth \\ and Fourth/Tenth Centuries
}

Edited by

Damien Janos

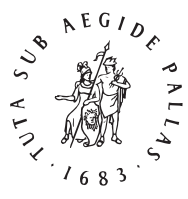

B R I L L

LEIDEN | BOSTON

For use by the Author only | (C) 2015 Koninklijke Brill NV 


\section{Contents}

List of Contributors VII

Introduction 1

1 The Syriac Aristotelian Tradition and the Syro-Arabic Baghdad Philosophers 7

John W. Watt

2 Palestinian Origenism and the Early History of the Maronites: In Search of the Origins of the Arabic Theology of Aristotle 44

Alexander Treiger

3 Some Observations about the Transmission of Popular Philosophy in Egyptian Monasteries after the Islamic Conquest 81

Ute Pietruschka

4 The Concept of ' $a q l$ in Early Arabic Christian Theology: A Case for the Early Interaction between Philosophy and kalām 109

Orsolya Varsányi

5 “Active Nature" and Other Striking Features of Abū Bishr Mattā ibn Yūnus's Cosmology as Reconstructed from His Commentary on Aristotle's Physics 135

Damien Janos

6 Between Hellenism, Islam, and Christianity: Abū Bakr al-Rāzī and His Controversies with Contemporary $\mathrm{Mu}^{\text {'tazilite Theologians }}$ as Reported by the Ash'arite Theologian and Philosopher Fakhr al-Dìn al-Rāzì $\quad 178$

Philippe Vallat

7 Theology as a Rational Science: Aristotelian Philosophy, the Christian Trinity and Islamic Monotheism in the Thought of Yahyā ibn 'Adī 221

Gerhard Endress 
8 What Does Tawhīd Mean? Yahyyā ibn 'Adī's Treatise on the Affirmation of the Unity of God between Philosophy and Theology 253

Olga Lizzini

9 Movement as "Discrete": Yaḥyā ibn 'Adī as a Source for the Ikhwān al-Ṣafā’? $\quad 281$

Carmela Baffioni

10 A Newly Discovered Yaḥyā ibn 'Adī Treatise against Atomism 298

David Bennett and Robert Wisnovsky

11 Aristotelian Cosmology and Causality in Classical Arabic Philosophy and Its Greek Background 312

David Twetten

Appendix: Recent Publications on Syriac and Arabic Christian Philosophy and the Baghdad School 435

Index of Names and Places 470

Index of Subjects 474 


\title{
What Does Tawhīd Mean? Yahyaā ibn 'Adī's Treatise on the Affirmation of the Unity of God between Philosophy and Theology
}

\author{
Olga Lizzini
}

There is no need to stress the importance of the term and the concept of tawhid in two closely interrelated intellectual domains of the Islamic tradition: theology and philosophy. The affirmation of the oneness and uniqueness of Godboth ideas are generally subsumed under the ambiguous term 'unity' - is at the center of Islamic theology (and not only as far as the Mu'tazilites are concerned). Tawhìd means, in fact, that unity (oneness and uniqueness) is recognized as such in God, and this concept forms the basis of Islamic theology. Together with 'ilm al-kalām, theology itself, as exemplified in al-Ghazālī, bears the simple name of 'ilm al-tawhīd, which indicates "the science of (divine) unity" or, literally, "the science of believing and affirming (divine) unity." One might even say that, from a theoretical point of view, Islam in itself is built on this foundation. Islam as such could be defined as the fundamental acknowledgement of a God who is absolutely one and unique, and hence the omnipotent sovereign who must be obeyed. Prayer, law, mysticism, rational efforts to conceive God, and even art find inspiration in Islam in this absolute idea of God. Analogously, and still from a theoretical perspective, the insurmountable difference between Islam and Christianity lies in the different conceptions of monotheism the two religions express: divine oneness and uniqueness have an absolute character in Islam, whereas in Christianity they give rise to an internal aporetic modulation which, in a sense, includes humanity within the limits of divinity. ${ }^{2}$

1 See, first of all, Gimaret, Tawhīd; Gardet and Anawati, Introduction à la théologie musulmane, index of technical terms (index des termes techniques), s.v. tawhìd; el-Bizri, God: Essence and attributes 121-40; Arkoun's contribution, Unité, in Amir-Moezzi, Dictionnaire du Coran 885-8, has a theoretical focus more than a historical one. For a recent assessment of the topic of the sources of kalām arguments, see Aradi, The origins of the kalām model 135-66.

2 See, most importantly, Thomas, Tathlīth. As regards Yahyā, see Platti, Yahyā ibn 'Adī, philosophe et théologien 167-84 (178-84 contain an edition and a translation of the Treatise in which the possibility of the humanization (al-ta'annus) of God is established: Traité qui établit la possibilité de l'humanisation et l'absurdité de la tenir pour impossible). 
In addition to its evident religious significance, the term tawhìd has an important philosophical history. The philosophical conception of the onewhich for the Aristotelian tradition was in a sense equivalent to being ${ }^{3}$ was to be distinguished from being in Neoplatonism. For the Neoplatonists, partly as a consequence of Plato's analysis in his Parmenides ${ }^{4}$ the one was also understood to be absolute and consequently separated from being (and existent things) and was identified with the Principle and therefore located in the transcendent divine sphere, which is something that can be said of nothing but the Principle itself. ${ }^{5}$

The objective of this introduction is to highlight the role Yahyā ibn 'Adī's Treatise on the affirmation of [divine] unity (Al-Maqāla fì l-tawhìd) plays in the Arabic-Islamic philosophical and theological traditions. ${ }^{6}$ The Treatise - as the title, which is of paramount importance, already suggests-refers to the fundamental concept of Islamic monotheism, on the one hand, and to the philosophical effort to find a logically coherent predication of the First Principle, on the other. It is on the basis of this premise that this contribution aims to offer a general introduction to the Treatise and to explain its inner structure (summarized in a schematic way in the Appendix). ${ }^{7}$ Apart from a few contributions on some particular aspects of the work (two of these contributions are my own), no detailed study has been devoted to the Treatise so far. ${ }^{8}$ But before we get into the heart of the question - what kind of Treatise is the Maqāla and what topics are dealt with in it-a few introductory words about its author seem advisable.

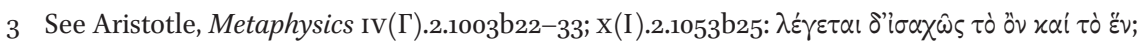
1054a16-9; cf., in general, $\mathrm{x}(\mathrm{I}) .1-2 ; \mathrm{IV}(\Gamma) .2 ; \mathrm{V}(\Delta) .6$. See, e.g., Makin, Aristotle on unity 77-103; Centrone (ed.), Il libro Iota della Metafisica di Aristotele; Castelli, Problems and paradigms of unity. For some remarks on the development of the theory of one and unity in Arabic thought, see Menn, Fārābī in the reception of Avicenna's metaphysics 51-96.

4 See at least Dodds, The Parmenides of Plato 129-42; Trouillard, Le «Parménide» de Platon 83-100; and now Turner and Corrigan, Plato's Parmenides.

5 See, e.g., D'Ancona, Causa prima 519-55.

6 For the text, see Yahyaā ibn 'Adī, Maqāla fì l-tawhìd; and Khalifat (ed.), Yahyyā ibn 'Adī: The philosophical treatises.

7 I am preparing a more detailed study together with an edition and translation of the text. A general description of the treatise can be found in Endress, Yahyā ibn 'Adī 312, 318-20.

8 See Bualwan, Introduction 485-95; Lizzini, Le traité sur l'unité 497-529; Lizzini, Critica dell"emanazione 225-44; Uluç and Argon, Reflections 133-61. 
Yahyā ibn 'Adī was a Christian (a member of the Syrian Orthodox Church of Antioch commonly called 'Jacobite'). He was born in Takrìt or Tikrìt in northern Iraq around 280/893 (between 280/893 and 281/894). He moved to Baghdad (probably in 302/915), where he attended the logical and philosophical school of Abū Bishr Mattā ibn Yūnus (d. 328/940) and al-Fārābī (d. 338/950); according to Ibn al-Nadīm he inherited the direction (al-riāsa) of the school. He probably remained at the head of the school for more than thirty years (this is, at least, what is traditionally reported about him, as is also his continuing to teach until he was almost eighty). ${ }^{9}$ Among the other reliable data about his life, a philosophical dispute with his brother Ibrāhīm seems worth mentioning. ${ }^{10}$ His brother, parenthetically, is believed to have been al-Fārābī's scribe (kätib) or secretary (mudawwin), ${ }^{11}$ and a recent hypothesis would even ascribe the Book on harmony (K. al-Jam' bayna ra'yay al-hakimayn Aflātūn al-ilāhì wa-Arisțutțāliss), traditionally attributed to al-Fārābī himself, to him. ${ }^{12}$ Yahyā ibn 'Adì died—as tradition reports—on 21 Dhū l-Qa'da 363/13 August 974 at the age of $81 .{ }^{13}$ His was a long life of research and study.

Although dominated by his religious orientation, the philosophical activity of Yahyā ibn 'Adī, who had also to copy manuscripts to earn a living, was extremely varied and intense. He was one of the most important translators of his time: as a native Syriac speaker he translated various Aristotelian works (or parts of works) from Syriac into Arabic, e.g., the Metaphysics (Books $\Lambda$ and M), ${ }^{14}$

9 See Ibn al-Nadīm, K. al-Fihrist: wa ilayhi intahat riāasat aṣhāäbihi fì zamāninā; cf. Endress, The works 6; Platti, Yahyyā ibn 'Adī: théologien chretien 6-7. Endress, Yahyāa ibn 'Adī 305-6 lists his pupils. Very general remarks can be found in Netton, Al-Farabi 8-11 and 55-63; Yahyā ibn 'Adī, Le traité de l'unité 30.

10 Cf. Endress, Die wissenschaftliche Literatur 451; Endress, The works 126; Khalifat, The philosophical treatises 29, notes 54-5; Yahyā ibn 'Adī, Le traité de l'unité 27-8.

11 Yahyā ibn 'Adī, Le traité de l'unité 27.

12 See Rashed, Al-Fārābī's lost treatise 19-58; idem, On the authorship 43-82. Arguments against al-Fārābī's authorship of the Book on harmony are expressed also by Janos in Al-Fārābī, creation ex nihilo 1-18. It must be said, however, that Janos is now inclined to maintain al-Fārābī's authorship: some of the positions held in the Book on harmony could be explained through a developmentalist interpretation of al-Fārābī's corpus; see Janos, Method 241-7.

13 See e.g., Endress, Yahyyā ibn 'Adī 304.

14 Clear indications of his translation concern only Books XII $(\Lambda)$ and XIII $(M)$. We also have a Commentary by Yahyā on Book II ( $\alpha$ ); cf. Endress, The works 27-8 and 38-9; Platti, Yahyā ibn 'Adī: théologien chrétien 25 and note; now Endress, Yahyyā ibn 'Adī 307. For the commentary, 
part of the Physics, ${ }^{15}$ and some treatises of the Organon: the Categories, Prior and Posterior analytics, the Topics, the Sophistical refutations ${ }^{16}$ and Poetics. ${ }^{17}$ As an author, he was active in the fields of logic, metaphysics, and ethics. A few examples give an idea of his philosophical interests: one treatise is about the difference between philosophy (logic) and grammar; according to Yahyā, who participated in this way in the debate which generally opposed philosophers to grammarians, ${ }^{18}$ universality pertains to logic, not to grammar. ${ }^{19}$ Other short treatises deal with physical and mathematical issues; ${ }^{20}$ some works analyze mainly metaphysical topics. ${ }^{21}$ Finally, a major work—the Tahdhïb al-akhlāq (The reformation of morals) — is dedicated to ethics. ${ }^{22}$ In addition, Yahyā devoted himself to theology and wrote several treatises on theological themes interpreted in the light of his Christian monophysitic credo. ${ }^{23}$ Moreover, his

see Yahyāa ibn 'Adī, Tafsìr li-l-maqāla al-ūlā min Kitāb Mā ba'd al-țabīa li-Arisțātālēs̄ 168-203. On the commentary, see Adamson, Yahyā ibn 'Adī and Averroes 343-74; Martini Bonadeo, The Arabic Aristotle 7-20; Martini Bonadeo, Un commento 69-96. By the same author cf. also, La tradizione araba della Metafisica $75^{-112}$. On the translations of Aristotle's Metaphysics, see Bertolacci, On the Arabic translations of Aristotle's Metaphysics.

15 Endress, The works 27: translation of Book II (revision of Ḥunayn's Syriac translation of the text with the commentary of Alexander of Aphrodisias); revision of the translation of Abū Rawh al-Sābī of Book I; cf. Peters, Aristoteles arabus 31-2.

16 The text is extant but very unclear and the attribution to Yahyā has been questioned; see Endress, The works 26-7; Platti, Yahyā ibn 'Adī: théologien chrétien Xx, 24 and note 98.

17 Endress, The works $25^{-6}$ and 28.

18 The paradigmatic example of this opposition is the public debate held in Baghdad in 320/932 in which the Muslim grammarian Abū Sacīd al-Sīrāfì debated with the Christian logician Abū Bishr Mattā; see Versteegh, Landmark ch. 4; Margoliouth, The discussion; Mahdi, Language and logic.

19 See Endress (ed.), Maqāla fì tabyīn al-fașl bayna șinā́atay al-manțiq al-falsafì wa-l-nạ̣w al-'arabī, in Grammatik und Logik 38-50; 181-93 (Arabic text); idem, Grammatik und Logik 163-299, in particular 272-96. A French translation in Elamrani-Jamal, Grammaire et logique 1-15; idem, Logique aristotélicienne 187-97; cf. Nahli, Yahyā ibn 'Adī 47-67; and the edition in Khalifat, The philosophical treatises 414-24. Cf. Endress, Yahyā ibn 'Adī 308. Cf. Périer, Yahyâ ben 'Adî 76 nn. 41-3; Khalifat, The philosophical treatises 31; Endress, Yahyā ibn 'Adī 303.

21 Khalifat, The philosophical treatises 32-6; Endress, Yahyā ibn 'Adī 303; Endress, The works 41-98 presents the following classification of his philosophical writings: (1) propaedeutics and logic; (2) physics and mathematics; (3) metaphysics (ontology and questions about kalām); (4) ethics; (5) various philosophical questions. Cf. Wisnovsky, New philosophical texts of Yahyāa ibn 'Adī 307-26.

Yaḥyā ibn 'Adī, Tahdhīb; The reformation of morals; cfr. Endress, Yaḥyā ibn 'Adī 303-4. On this treatise, see Zilio-Grandi, Il "Kitâb tahdhîb al-akhlâq" 273-83.

23 Cf. Périer, Yahyâ ben 'Adî 66-7; Endress, The works 99-123. 
theological concern was never separate from his philosophical knowledge. In many of his theological treatises he deals with general issues of philosophical theology by means of the Aristotelian theory of demonstration (and by means of the Aristotelian dialectics). This is clear also in the works he dedicated to kalām, the most important of which are in a sense 'political,' since they are focused on the central concepts of the Islamic religion. As Endress writes: "The universals they discuss are concepts of Islamic theology and the questions they mean to resolve are the aporias of Kalam."24 As is well known, in the society of Yahyā's time, cultivated Christians who knew the ancient languages, such as Greek and Syriac, were for the Muslims an unavoidable point of reference in the quest for knowledge. Fourth-/tenth-century Baghdad was not only a center of understanding and cooperation, but also of criticism and debate. Nonetheless, Muslim, Christian and Jewish scholars spoke the common language of Greek science and Aristotelian logic. And the significance of this interaction of languages, religions, and points of view is clearly perceptible in Yahyā, who could be defined as a characteristic figure of the climate of communication of his period.

2

It is with this in mind that one should read the Treatise on the [divine] unity or On the affirmation of [divine] unity (Al-Maqāla fì l-tawhīd), a treatise which is at once both philosophical and theological. Yahyā analyses the different meanings of the word 'one.' He does it not only in terms of its logical sense (how should the one be understood in terms of logical or even linguistic analysis?), but also in terms of a proper understanding of the divine unity. The contents of the treatise, its structure, and the technique with which it is written are philosophical: Yahyā works mainly with the arguments of Aristotle's logic and his most direct sources and/or precursors seem to be Aristotle's Physics (in particular I.2) and Metaphysics (in particular $\mathrm{IV}(\Gamma) .4 ; \mathrm{X}(\mathrm{I}) .6$ ), ${ }^{25}$ whereas indirect sources or references can be found in the Neoplatonic and Graeco-Arabic doctrines about the one. The goal of the Treatise must be viewed as theological (to describe God) and apologetic (to defend the Christian description of God). The result is a Trinitarian formulation of divine unity, which, in contrast to the absolute doctrine of Islam, reveals a relative or "modulated" understanding of monotheism.

\footnotetext{
24 Endress, Yahyā ibn 'Adī 318.

25 But cf. Aristotle, Metaphysics v( $\Delta) .6$ and XIV(N).1087b30-1088a14.
} 
As already stated, the Treatise comprises a discussion of different views on the meaning of one (wāhid) and unity (wahdāniyya). By means of this work Yahyā ibn 'Adī sets out to prove that predicating diversity within unity and therefore within the unity of God is, logically speaking, not simply possible, but necessary.

The beliefs or opinions (itiqādāt) and the various teachings (aqwāl) on the one and unity, from which Yahyā's discourse springs, are themselves based on a dialectical scheme that ultimately forms the very structure of the essay (see the Appendix). They can be divided into two groups: (a) the first consists of the doctrines on the meaning ( $\left.m a^{\prime} n \bar{a}\right)$ of the one and unity, which must be ascribed to God, the Creator of the world (ma'nāwahdāniyyati l-khäliq), as they concern the one and unity (oneness and/or uniqueness) in themselves; (b) the second group includes those theories that should give an answer to the hypothetical question of whether God is one in every respect, diverse or multiple in every respect, or finally one in certain respects and multiple in others.

These two different approaches, which Yahyā de facto distinguishes in his Treatise, are not conceptually equivalent. In the first, the terms for the one and oneness and/or uniqueness are first precisely determined as such and subsequently discussed according to the idea of the oneness and/or uniqueness of God. Accordingly, in this first group, a philosophical concept of unity serves as a distinguishing feature. Only on closer inspection does a theological interest appear. On the contrary, the second group focuses on the teachings about the idea of the oneness of God. Thus it poses a typical theological question, namely that of the divine identity. In other words, the teachings under discussion in this second group seem to make a logical point: one can discuss the oneness and uniqueness of God only if one has already defined the one itself, on the one hand, and God as one, on the other. Moreover, in this second group the two already mentioned opposite conceptions of God are recognizable: the (essentially Islamic) view of the absolute uniqueness of God (the question "Is God one?" receives a radical answer: God is unqualifiedly or absolutely "one"), as opposed to the (essentially Christian) view, according to which God is oneand-three and therefore "one in one respect and multiple in another respect."26 However, Yahyā builds up his discourse within the limits of a purely abstract language and neither Islam nor the Christian creed are explicitly named.

The inner distinctions in these two groups of theories-i.e., respectively, teachings on the one and answers to the question of divine unity-explain the inner divisions of the first part of the Maqāla fì l-tawhìd. For this seems in turn to be divided into two conceptual parts: the first is devoted to the explanation of the different teachings about the one; in this respect, this part aims 
to establish a definition of oneness and unity which could justify what Yahyā considers the necessary diversity inherent in them. The other part deals with the clarification of the proper conception of God as "one," which arises from the Christian point of view according to which God is "one in a sense and diverse or multiple in another sense." Nevertheless, the structure of the Treatise might be explained instead on the basis of a different conceptual distinction. In fact, whereas the first part of the essay refutes the different meanings of the one and unity and is thus to be seen as a pars destruens, so to speak, the second could be considered a pars construens. ${ }^{27}$ Indeed, in the second part Yahyā not only builds up the "symbol" of the triple, i.e., "Trinitarian" divine unity, but also explains and justifies it, unfolding his concept of God as one and plural and therefore as qualified by "power" (qudra), generosity ( $j \bar{u} d)$, and wisdom (hikma), three attributes (șifāt) of God that can be recognized in both the philosophical and religious traditions. ${ }^{28}$

Schematically, the ideas that constitute the first group are the following:

(1) The predicate 'one' means just the negation of plurality and should not be taken as an affirmation of God's unity. ${ }^{29}$

(2) "God is one" means He has no equals. ${ }^{30}$

27 I referred to this distinction also in my Le traité sur l'unité de Yahyā ibn 'Adī.

28 For the religious tradition, see Gimaret, Tawhīd 389; idem, Les noms divins en Islam, s.v. Cf. Aradi, The origins of the kalām model 151-4; for the philosophical (Proclean and PseudoDionysian) tradition, see Endress, Yahyā ibn 'Adī 320: Proclus indicates agathotes, dynamis, gnosis as constituting the first divine triad (Theologia platonica, I, XVI, 44; cf. Elem. theol., prop. 121); in Pseudo-Dionysius sophia is indicated at the place of gnosis, as in the Patristic tradition. As already mentioned, discussing the theoretical sources and precursors of Yahyā's Treatise lies beyond the limits of the present contribution. Nevertheless, it must be stressed that the concern about a proper definition of divine Trinity and therefore the use of Neoplatonic sources is to be recognized also in other Arabic Christian works. The most interesting example is probably the Treatise on the unity and trinity of God ascribed by Bo Holmberg to the Nestorian Israel of Kashkar (Isrāîl al-Kaskarī, died 258/872; see Israel of Kashkar, A treatise on the unity and trinity of God by Israel of Kashkar). This text admits a unity of species in God and three properties (khawāșs) which are hypostases (aqūnīm) and include life and reason (see also Daiber, Buchbesprechung 401-2).

29 See Yahyyā ibn 'Adī, Le traité de l'unité 160 and $165^{-7}$.

$30 \quad$ Ibid. 161 and $168-78$.

For use by the Author only | (c) 2015 Koninklijke Brill NV 
(3) "Being one"-(even when) applied to God-is the same as being the principle of number i.e., of numeration. ${ }^{31}$

(4) "God is one" has no particular meaning as regards the other existent things in the world; in other words, the concept of the one must be explained in the general terms applied to the concept of unity when it is used to describe anything in the world: "being one" thus has no special meaning when applied to God. ${ }^{32}$

Apart from the inner philosophical or theological meanings of these distinctions, the exact doctrines to which Yahyā refers here as well as his sources cannot be definitively established. In a sense, the most important thing is not so much to identify the authors Yahyā intends to rebut in relation to each of these positions, but the positions themselves. Moreover, one cannot exclude the possibility that Yahyā aims to discuss doctrinal points rather than specific authors. It is in the light of this premise that one can tentatively indicate some approaches and a possible source and/or critical reference for each of the positions discussed in the Treatise; and this, bearing in mind that the partition of the doctrines or beliefs may not be strictly interpreted. In fact, the positions that Yahyā presents as distinct often turn out to be overlapping or interwoven.

As highlighted by Gerhard Endress, the first view (the predicate "one is nothing but the negation of plurality") simply coincides with the Islamic confession of faith. In fact, the first part of the shahäda, which states, "there is no god but God" (lā ilāha illa Allāh) can be understood as equivalent to an absolute negation. ${ }^{33}$ To this theological reference an explanatory philosophical hypothesis might be added: the negation of plurality may in fact correspond to the Neoplatonic via negativa, whereby the plurality of God is negated without automatically proving the unity or oneness of God. According to this theoretical movement, if nothing can be affirmed about God, then everything about Him must be denied, so that neither a predication nor an affirmation, but instead a super-predication is the only possibility (which ultimately leads to a via and theologia superlativa).

The second view ("The One/God has no equal") clearly corresponds to the Islamic formula "God has no equal" ${ }^{44}$ (or associate or companion), ${ }^{35}$ but here

\footnotetext{
$31 \quad$ Ibid. 161 and $179-83$.

32 Ibid. 162 and $184-93$.

33 Endress, Yahỵā ibn 'Adī 318. See $Q$ 3:18; 6:19; 21:25; 92; 108; 23:91-2; 28:70; 37: 4; 44:8; 112:1-4.

34 See, e.g., $Q$ 2:22; 112:4.

35 See, e.g., $Q$ 4:48; 116; 12:38; 16:22; 51; 17:42; 23:92; 25:2; 26:213; 27:59-64; 30:13; 72:18-20. Quranic references are interrelated: to the verses denying the existence of associates of
} 
too a philosophical counterpart can be identified. In his metaphysical worktraditionally viewed as political and called The perfect state or The virtuous city (K. fimabādi' ärä'ahl al-madina al-fädila: The book on the principles of the views of the inhabitants of the perfect or ideal or virtuous city) —al-Fārābi ${ }^{36}$ expresses this concept at the very beginning: nothing else exists on the level of the existence of the First: ([...] al-awwalu munfarid ${ }^{u n}$ bi-wujūdihi lā yushārikuhu shay'un aṣlan mawjüdun min naw ‘i wujūdihi [...]). ${ }^{37}$ The reference to al-Fārābī can be explained by his association with Yahyā ibn 'Adī in the context of what is traditionally designated as the Baghdad School. The book on the one and the unity (K. fì l-wāhid wa-l-wahda), in which al-Fārābī associates with each meaning of one and unity a meaning belonging to multiplicity, is certainly one of the forerunners of Yahyā's Treatise on the (divine) oneness and unity. Furthermore, even if one could make a probable guess with regard to the identities of a number of authors at whom Yahyā ibn 'Adī's Treatise was aimed, authors distinctly dissimilar can actually be grouped together under the same doctrinal position. In fact, the idea that God has no equals (and therefore the aporetic notion that He can have no proper relationship with the world), can be found, as Samir Khalil Samir has already noted, in various Christian authors, who refer to the idea of non-existent equals as a sign of the oneness of God. This position can be recognized - albeit in a form devoid of philosophical argumentation - in the Syrian Antiochian Abū Rāița al-Takrīìi (d. after 213/828), who was, like Yahyā, an orthodox monophysite. ${ }^{38}$ But this is just an example. Finally, here too one

God one should add those denying the existence of God's son (or children) and more generally against idolatry.

36 For an in-depth study of al-Fārābī's philosophy, see Vallat, Farabi. On the interrelation of metaphysics and cosmology, see Janos, Method.

37 See Al-Färābì on the perfect state 66,5-6. For the reference to al-Fārābī see also Bader, L'unité-multiplicité 19off. and cf. Vallat, Farabi 68-73, in particular 70: "l'Un [...] ne possède pas le moindre noème ( $m a^{\text {cnna }}$ ) en commun avec le reste des étants et qui serait susceptible de varier d'intensité hors de Lui." Vallat connects al-Fārābī's theory with the texts of Arabic Neoplatonism and, partly, with Porphyry. In a way, Arabic philosophy attempted to find a harmony between the Aristotelian idea of being, which is also one, and the Neoplatonic conception of the one, which is not being: the Principle, which is one, is not one of the other beings but is nevertheless a being. Interestingly enough, in his Book on one and unity, al-Fārābī speaks about the things which are one because they have no equal or peer (qasim) and includes among them what is single in its existence (munfaridan bi-l-wujūd) like the moon or one of the celestial bodies (kawkab). Even Aristotle is said to be one or unique in this respect, since he had no equal (or peer) in the knowledge of philosophy; see Alfarabi's On one and unity $55^{-6}$.

38 Cf. Keating, Refuting the charge of tahrîf 41-57; Suermann, Habïb ibn Hidma 221-33. 
might detect Neoplatonic inspiration in the idea of the necessary uniqueness of the Principle, because of the impossibility of having two equal principles. ${ }^{39}$

Yahya ascribed the third position to a contemporary theologian whose name he refrains from mentioning. ${ }^{40}$ In any case, this position seems to be the

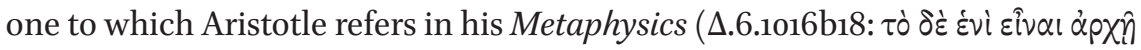

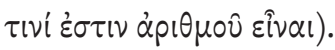

The fourth doctrine seems to deal with the general logical argument behind the Aristotelian conception of unity and being as two synonymous terms. ${ }^{41}$ In fact, if being is to be understood as one ("to be" always means "to be one"), then "to be God" simply means "to be one God." Nevertheless, as Yahyā notes, this cannot mean that we consider divine unity to depend on unity in a universal sense; if this were indeed the case, many paradoxes would arise. How could God depend on an accident?

One should, however, bear in mind the fact that the distribution of the doctrines or beliefs just mentioned cannot be conceived in a strict sense. The positions Yahyā introduces as distinct often present a mutual superposition or intertwinement in theoretical terms. For instance the definition of the oneness or unity of God on the basis of His absolute otherness (God has no equals) is theoretically consistent with the view whereby the oneness or unity of God goes beyond the general way of being and predication. In this respect, this view is not inconsistent with the doctrine whereby the oneness or unity of God surpasses the general way of being. Analogously and still on a purely theoretical level, the fourth doctrine, which can be considered a clarification of the multiple meanings of unity, also turns out to be not inconsistent with the position that Yahyā ibn 'Adī himself uses in defining the unity of God.

39 See note 37 on Vallat's hypothesis; the affirmation that there cannot be two equals is logically argued in Proclus's Elements of theology (Prop. XXII). On the controversial question of the familiarity with the Elements of theology in the Arabic world, see Endress, Proclus de Lycie 1662-8 in particular. On the importance of Proclus in understanding the philosophy (and the cosmology) of al-Fārābì, see Janos, Method. The problem of the uniqueness of God is similarly stated by Muslim theologians: as Gimaret put it: "if there were two gods, they [the theologians] assert, there would inevitably arise between them, at one time or another, a conflict of wills" (E.I., s.v. Tawhīd 389 and Gimaret, La doctrine d'al-Ash'ari 252-4, with references included); the essential Quranic reference is 21:22: "If there were numerous gods instead of one, [the heavens and the earth] would be in a sorry state." As one might marginally notice, Avicenna too has an argumentation against the plurality of the Principles (see e.g., Shifä̀), Ilāh. I.6.39,17-42,7).

41 See Aristotle, Metaphysics $\operatorname{IV}(\Gamma) .2 ; \mathrm{x}(\mathrm{I}) .2$ and $1053 \mathrm{~b} 25$ in particular; cf. Physics 185b6. 
The second part of the Treatise begins once all these notions have been refuted. Thus what we have defined as the pars construens has a precise aim. Its task is to prove (ithba $\bar{t}$ ) that the Creator is one "in one respect and multiple or diverse in other respects." ${ }^{22}$ How does Yahyā go about proving this?

As an (Aristotelian) logician, he analyzes the different philosophical meanings of the term 'one.' In fact, following Aristotle's distinctions, something can be described as one or as a genus (jins), a species $\left(n a w^{c}\right)$, a relation (nisba), a continuum (muttașil), a definition (hadd), or indivisible (ghayr munqasim). ${ }^{43}$ The latter may even have two different meanings: it can be understood as a negation of divisibility (in either an existing or a non-existing object), or instead as the principle of all divisible things.

For each meaning, Yahyyā identifies some correspondences or oppositions (munāzarāt) and aspects (jihāt): actu/potentia;per se/per accidens; subject and definition. As a result, Yahyā relativizes the concept of the one. Every aspect of the one corresponds to an aspect of diversity: the very same thing is one according to one aspect and multiple according to another. By enumerating the aspects that belong to multiplicity and diversity and correspond to aspects that apply to the one, ${ }^{44}$ Yahyā extracts from the one the "diversity" inherent in it. What is one is always multiple, and "the one itself" is one, on the one hand, and diverse and multiple, on the other. In Yahyā's view the relativity that ideas of the one and unity reveal does not indicate an aporetic character; instead it definitely offers the possibility of predicating multiplicity and diversity as inherent in the one itself. In that respect, the relativity that inheres in the ideas of the one and unity gives our author the legitimacy required for speaking of the inner "plurality" of divine unity. God, Yahyā says, is both one and multiple in terms of His definition (and therefore in actu and per se). In fact, the only division of the one that can be attributed to God is definition: the so-called definition of God is one, and the aspects (wujūh, jihāt) by virtue of which we are allowed to say that God is "one" are: act, essence, and subject/definition. ${ }^{45}$ But, as already stated, analysis of the one provides Yahyā with the legitimacy he needs if he is to speak of the inner "plurality" of divine unity. Thus, by applying the same method he had previously used to determine the unity of God, he establishes the senses or aspects by virtue of which God is called "many": these

\footnotetext{
42 See Yahyā ibn 'Adī, Le traité de l'unité 222 and ff.

43 Here too see, e.g., Aristotle, Metaphysics v( $\Delta) .6$; Physics v(E).4.

44 See Aristotle, Metaphysics $\mathrm{v}(\Delta) \cdot 6.1016 \mathrm{bg}-11 ; \mathrm{x}(\mathrm{I}) \cdot 3-6$.

45 Yahyā ibn 'Adī, Le traité de l'unité 231-2.
} 
are the very same meanings he established for the unity of God. In the Treatise he comes, in fact, to the paradoxical conclusion that God is many in terms of His definition, exactly as He is one in terms of His definition. Yet from Yahyā's standpoint this involves no contradiction: since it is 'discourse,' the definition is necessarily composite (Yahyā mentions the 'parts' of the definition, which are due to the composition of a subject and a predicate), so that it is perforce the sign of a certain multiplicity. On the basis of similar reasoning - one might note-a stricter philosophical tradition rejects the possibility of giving any definition of God (see, e.g., Avicenna). ${ }^{46}$

Having just proved that the term and the concept of one are-as one might say — relative, that is to say not absolute, Yahya proves that even the oneness and uniqueness of God are relative. In other words, according to our perspective, things are both one and multiple at the same time and God is no exception: God is one and unique, but also not-one (and therefore not unique) or, more precisely, God is one and unique in a non-absolute manner. But although Yahyā's aim in this Treatise is clearly theological, the language he uses is strictly philosophical: God is even identified as the "Cause of causes" or the "First Cause" ('illat al-ilal; al-illa al-ülā $).{ }^{47} \mathrm{In}$ fact—as we have seen-Yahyā does not simply assert that God is one in one respect, and manifold or multiple in another, but that the one is in itself multiple and manifold. It is the concept of one as such that must be ascribed both to unity and to diversity and multiplicity. 48

The plurality ascribed to divine unity is therefore a function of the plurality to be found within unity itself. In this respect, Yahyā does not deal with the question of the divine attributes directly: that question is posterior to the discussion about the concepts of oneness and unity, which must be understood to imply multiplicity and diversity, from a certain point of view. ${ }^{49}$ In themselves,

46 Specifically Metaphysics VIII.4.348,5; VIII.5.354,11. Avicenna does not refer to the linguistic composition of subject and predicate (Yahyā speaks of the definition as a discourse), but to the philosophical composition of genus and specific difference.

47 Yahyā ibn 'Adī, Le traité de l'unité 215.

48 Obviously, the "third-man" problem is lying in wait here: the very unity which is ascribed to the one would be one, on the one hand, and multiple, on the other.

49 Using the term șifät - the common ground of theological discourse for Arabic speakers, whether Muslim or Christian — to indicate hypostases was a common practice; see, e.g., Griffith, The concept 169-91; idem, The Kitāb Misbāḥ al-'aql 15-42. 
however, God's attributes can be recognized through His effects and works. Three attributes render the effects of God's creation visible: generosity $(j \bar{u} d)$ or goodness, power (qudra; hawl) and wisdom (hikma). As can be seen, the multiplicity of God in this case assumes the character of a triplicity or triad that, while not explicitly identified with the Trinity by Yahyā, clearly alludes to it. As Gerhard Endress's research has shown, this kind of triad or trinity—which Yahyā would later replace with the Aristotelian triadic movement of "intelligent, intelligence, and intellect" ('äqil - 'aql - ma'qūl)—is actually a remnant of the philosophical tradition that antedated Yahyā and has its roots, either directly or indirectly, in the Neoplatonic speculation of Proclus. The three attributes of the Creator-goodness, power, and wisdom (the cardinal attributes of

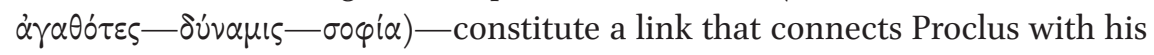
Christian follower, Pseudo-Dionysius the Areopagite. ${ }^{50}$

Discussing the theoretical sources and precursors of Yahyā's Treatise would be very useful, but it lies beyond the limits of the present contribution. Three philosophical works (or groups of works) should at any rate be considered: (a) the immediate sources are in fact-as already stated-Aristotle's Metaphysics and Physics; (b) to these one should add, as a fundamental forerunner, the Book (or Epistle) on first philosophy by al-Kindī (d. ca. 256/870), where the idea of God as one is elaborated using both Aristotle's Metaphysics and Proclean sources; ${ }^{51}$ (c) finally, as we have already stated, a crucial source seems to be the Bookon the one and unity (K. fì l-wāhid wa-l-waḥda) by al-Fārābī (d. 338/950), where an aspect of plurality is associated with each aspect of unity (al-Fārābī explicitly speaks about what is not one as something which is opposite and/or correspondent—muqābil— to what is one)..$^{52}$ This Farabian text, which could be considered (and this is partly true for Yahyầ's text itself) as an answer to the question of what is one and what is not one or multiple, ${ }^{53}$ is divided into two parts: the first deals with the different ways in which things

50 See supra note 28. On Dionysius, see Klitenic Wear and Dillon, Dionysius the Areopagite.

$5^{1} \quad$ Risāla or Kitāb fì l-falsafa al-ūlā; see Ivry, Al-Kindi's Metaphysics, but cf. Neuwirth, Neue Materialien 84-100. On al-Kindī, see Adamson, Al-Kindī, the chapter on metaphysics, particularly 47-57; on al-Kindī (and Greek sages) as sources for the discourse about divine oneness, see Wakelnig, Greek Sages on the Tawhīd.

$5^{2}$ Al-Fārābī, On the one and unity 57,12: wa mā laysa bi-wāhid muqābil mā huwa wāhịid.

53 See Vallat, Farabi 64 note 3, who mentions Plato's Parmenides 136a as a possible source to explain the structure of the Treatise. In any case, Aristotle's Metaphysics (A.5, B.4 and N) is a crucial textual reference for the Treatise, together with Aristotle's Physics (I.2 and 3) and with Simplicius's Commentary on Aristotle's text. 
are said to be one (wähid), while the second deals with the different ways in which things are said to be multiple or many (kathīr). Morever, al-Fārābì's text contains the statement that multiplicity can be numerically one (one in number) according to what one might call different perspectives: the genus, the species, or the accident, for example. Al-Fārābì's text identifies also the one that is said in relationship to the definition - that is to say, in relationship to

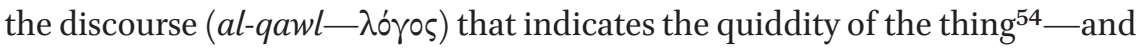
the one which is said of the continuum and the compositum (but there are many other similarities with Yahyā's text). In his analysis, al-Fārābī finds a correspondence in multiplicity for almost every kind of 'one' but not—as Yahyā does - for every kind of 'one.' In fact, the aim of al-Fārābī seems to be simply that of analyzing the analogy (not the simple equivocity) of the concept of one, which is said in many ways exactly as being is (The treatise on one and unity begins in fact with the assertion that "the one is said in many ways": al-wāhid yuqāl 'ala anhä $\bar{a}^{3}$ kathìra). ${ }^{55}$ In other words, although one can safely assume that al-Fārābī's text (together with Aristotle's) is the main source of Yahyā's text, the aim it shows is not the same as Yahyaās: al-Fārābī does not intend to deduce that everything which is one is also multiple. His metaphysics implies the idea of an absolute one, ${ }^{56}$ and what we called the "non absoluteness" or the "relativity" of the idea of oneness (and of divine oneness) cannot be ascribed to him.

Moreover, as should be clear, the philosophical references of Yahyā's text are always to be understood in relation to theological questions. For, just as behind the rejected positions we can find both philosophical and theological doctrines, so behind the logical analysis of the second part of the Treatise Christian doctrinal distinctions are often detectable. Implicitly, the theses of the Treatise refer not solely to Yahyā ibn 'Adī's philosophical and theological work, but also to the entire philosophical and theological tradition to which they belong. The Treatise on the affirmation of the (divine) unity (or on the affirmation of the oneness or unity of God) is part of the reflection on the one and the unity of the First Principle, which not only represents one of the fundamental topics of the philosophical and theological speculation of medieval Islam, but also constitutes a fundamental issue of philosophy in general.

\footnotetext{
54 See Alfarabi's On one and unity 37 and 55 and in general $36-44$.

55 Alfarabi's On one and unity, $36,8$.

$5^{6}$ See for example al-Fārābī, On the perfect state I, 57 and ff.
} 


\section{Works Cited}

\section{Primary Sources}

al-Fārābī, Abū Nașr, Alfarabi's On one and unity, ed. Mahdi, M., Casablanca 1989.

— Al-Farabi on the perfect state: Abū Nașr al-Fārābỉs Mabādi’ ārā' ahl al-madīnat al-fādilah, revised text with introduction, translation and commentary by Richard Walzer, Oxford 1985, repr. Chicago 1997.

Ibn al-Nadīm, Abū l-Faraj Muhammad ibn Isḥāq, K. al-Fihrist, ed. Flügel, G., Müller, A. and Rödiger, E., Leipzig 1871-2.

Israel of Kashkar, A treatise on the unity and trinity of God by Israel of Kashkar (d. 872). Introduction, edition and word index by Bo Holmberg (Lund studies in African and Asian religions, 3), Lund 1989.

al-Kindī, Al-Kindi's metaphysics: A translation of Ya'qub ibn Ishaq al-Kindi's treatise "On first philosophy" (F⿱ al-falsafah al-ūlā), trans. Ivry, A.L., Albany 1974.

Yahyā ibn 'Adī, The reformation of morals, a parallel English-Arabic text, translation and introduction by S.H. Griffith, Provo (Utah) 2002.

— , Tahdhīb al-akhlāq, ed. al-Āb Samīr Khalīl al-Yasūwī, al-Qāhira 1994 (Tahdhīb al-akhlāq, text edited and structured by Samir Khalil Kussaim, sJ, Beirut, Cairo 1994).

— Y Yahyā ibn 'Adī: The philosophical treatises, ed. Khalifat, S., University of Jordan, Amman 1988 (Maqālāt Yahyyā ibn 'Adīal-falsaftyya, ed. Khalīfāt, S., 'Ammān 1988).

—_, Maqāla fì l-tawhìd li-l-shaykh Yahyā ibn 'Adī (893-974). Le traité de l'unité de Yahyā ibn 'Adī, ed. Samir, S.Kh., Jounieh, Rome 1980.

\section{Secondary Literature}

Adamson, P., Yahyā ibn 'Adī and Averroes on Metaphysics Alpha Elatton, in Documenti e studi sulla tradizione filosofica medievale, 21 (2010), 343-74.

, Al-Kindī, Oxford 2007.

Aradi, N., The origins of the kaläm model of discussion on the concept of tawhìd, in Arabic sciences and philosophy, 23.1 (2013), 135-66.

Arkoun, M., Unité, in Amir-Moezzi, M.A. (ed.): Dictionnaire du Coran, Paris 2007, 885-8.

Arnzen, R. (ed.), Platonische Ideen in der arabischen Philosophie. Texte und Materialien zur Begriffsgeschichte von șuwar aflāțūniyya und muthul aflātūniyya, Berlin 2011.

—. Plato, Arabic, in Encyclopedia of medieval philosophy, ed. Lagerlund, H., Amsterdam 2011, 1012-6.

, Arabisches Mittelalter, in Horn, C., Müller, J. and Söder, J. (eds.): PlatonHandbuch. Leben - Werk - Wirkung, Stuttgart, Weimar 2009, 439-45. 
Bader, Gh., L'unité-multiplicité de l'un premier selon Ibn 'Adī. Approches historicophilosophiques à son traité de l'unité, Dissertatio ad lauream, Pontificia Universitas Lateranensis, Rome 1985.

Bertolacci, A., On the Arabic translations of Aristotle's Metaphysics, in Arabic sciences and philosophy, 15.2 (2005) 241-75.

Bualwan, K., Introduction of Yahyā ibn 'Adī's (†974) conception of the one in the treatise on unity, in Parole de l'Orient, 28 (2003), 485-95.

El-Bizri, N., God: Essence and attributes, in Winter, T. (ed.): The Cambridge companion to classical Islamic theology, Cambridge 2008, 121-40.

Castelli, L.M., Problems and paradigms of unity, Sankt Augustin 2010.

Centrone, B. (ed.), Il libro Iota della Metafisica di Aristotele, Sankt Augustin 2005.

Combès, J., Négativité et procession des principes chez Damascius, in Bertier, J. et al. (eds.): Recherches sur la tradition platonicienne (Platon, Aristote, Proclus, Damascius), Paris 1977, 119-41.

D’Ancona, C., Causa prima superior est omni narratione: il tema delle Șifât Allāh nel primo neoplatonismo arabo, in Oriente moderno, 19 (80 n.s.; 2000), 519-55.

Daiber, H., Buchbesprechung: A treatise on the unity and trinity of God by Israel of Kashkar (d. 872). Introduction, edition and word index by Bo Holmberg (Lund studies in African and Asian religions, 3), Lund 1989, in ZDMG, 141 (1991), 401-2.

Dodds, E.R., The Parmenides of Plato and the origin of the Neoplatonic "One," in Classical quarterly, 22 (1928), 129-42.

Elamrani-Jamal, A., Logique aristotélicienne et grammaire arabe: études et documents, Paris 1983 .

— Grammaire et logique d'après le philosophe arabe chrétien Yahyā ibn 'Adī (280-364 H/893-974), in Arabica, 29 (1982), 1-15.

Endress, G., Yahyyā ibn 'Adī, in Rudolph, U. (ed., unter Mitarbeit von R. Würsch): Philosophie in der islamischen Welt, Band 1, 8.-10. Jahrhundert, Grundriss der Geschichte der Philosophie, Basel 2012, 301-24.

— tion de R. Goulet, Paris 2012, Vb, 1546-674 [1662-8 in particular].

- Die wissenschaftliche Literatur, in Gätje, H. (ed.): Grundriß der arabischen Philologie, Band II: Literaturwissenschaft, Wiesbaden 1987, 400-506.

— Grammatik und Logik: Arabische Philologie und griechische Philosophie im Widerstreit, in Mojsisch, B. (ed.): Sprachphilosophie in Antike und Mittelalter, Amsterdam 1986, 163-299.

—_, Grammatik und Logik: Eine Schrift von Yahyā ibn 'Adī und ihre Vorgeschichte, in Majallat tā'rīkh al-ulüm al-'arabiyya (Journal for the history of Arabic science), 2 (1978), 38-50; 181-93 (ar.) [also as The treatise of Yahyā ibn 'Adī 'On the difference between philosophical logic and Arabic grammar'].

-, The works of Yahyā ibn 'Adī: An analytical inventory, Wiesbaden 1977.

Gardet, L., Anawati, G.C., Introduction à la théologie musulmane, Paris 1948, repr. 1981. 
Gimaret, D., Tawhīd, in $E I^{2}$, ed. Bearman, P. et al., Brill online 2015.

— La doctrine d'al-Ash'ari, Paris 1990.

- Les noms divins en Islam: exégèse lexicographique et théologique, Paris 1988.

Graf, G., Geschichte der christlichen arabischen Literatur, 5 vols., Città del Vaticano 1944-53.

Griffith, S.H., The church in the shadow of the mosque: Christians and Muslims in the world of Islam, Princeton, N.J. 2007.

— The Kitāb Misbāh al-'aql of Severus Ibn al-Muqaffa': A profile of the Christian creed in tenth century Egypt, in Medieval encounters, 2.1 (1996), 15-41.

— The concept of al-uqnüm in 'Ammār al-Bașrī's apology for the doctrine of the Trinity, in Samir, S.Kh. (ed.): Actes du premier Congrès international d'études arabes chrétiennes (Goslar, septembre 1980), Rome 1982, 169-91.

Husseini, S. L., Early Christian-Muslim debate on the unity of God, Three Christian scholars and their engagement with Islamic thought (gth Century CE), Leiden 2014.

Janos, D., Method, structure, and development in al-Färäbì's cosmology, Leiden, Boston 2012.

, Al-Fārābī, creation ex nihilo, and the cosmological doctrine of the K. al-Jam ${ }^{c}$ and the Jawābāt, in JAOS, 129 (2009), 1-18.

Keating, S.T., Refuting the charge of tahrī̄: Abū Rāita (d. ca. 835) and his "First risāla on the Holy Trinity," in Günther, S. (ed.): Ideas, images, and methods of portrayal: Insights into classical Arabic literature and Islam, Leiden, Boston 2005, 41-57.

Klitenic Wear, S. and Dillon, J., Dionysius the Areopagite and the Neoplatonist tradition: Despoiling the Hellenes, Aldershot 2007.

Krämer, J.L., Humanism in the renaissance of Islam: The cultural revival during the Buyid Age, Leiden 1986, 1993².

Lizzini, O.L., Critica dell"emanazione e creazione dal nulla in Yahyā ibn 'Adī, in Righi, D. (ed.): La letteratura arabo-cristiana e le scienze nel periodo abbaside (7501250 DC): atti del $2^{\circ}$ Convegno internazionale, Pontificio Istituto Orientale 9-10 marzo 2007, Torino 2008, 225-44.

—_ Le traité sur l'unité de Yahyyāibn 'Adīe t la troisième Maqālah de la Métaphysique du Kitāb al-Šifä' d'Avicenne: deux finalités différentes dans l'analyse de l'un, in Parole de l'Orient, 28 (2003), 497-529.

Mahdi, M., Language and logic in classical Islam, in von Grunebaum, G.E. (ed.): Logic in classical Islamic culture, Wiesbaden 1970, 51-83.

Makin, S., Aristotle on unity and being, in Proceedings of the Cambridge philological society, NS 34 (1988), 77-103.

Margoliouth, D.S., The discussion between Abu Bishr Matta and Abu Sa'id al-Sirafi on the merits of logic and grammar, in JRAS, 37 (1905), 79-129.

Martini Bonadeo, C., The Arabic Aristotle in the 1oth century Bagdad: The case of Yahyā ibn 'Adī's Commentary on Metaphysics. Alpha Elatton, in Veritas: Revista da Pontificia Universidade Catolica do Rio Grande do Sul, 52 (2007), 7-20.

\section{For use by the Author only | (C) 2015 Koninklijke Brill NV}


, Un commento ad Alpha Elatton «sicut litterae sonant» nella Baġdād del x secolo, in Medioevo, XXVIII (2003), 69-96.

— La tradizione araba della Metafisica di Aristotele. Libri a-A, in D'Ancona, C. and Serra, G. (eds.): Aristotele e Alessandro di Afrodisia nella tradizione araba: attidel Colloquio "La ricezione araba ed ebraica della filosofia e della scienza greche," Padova, 14-15 maggio 1999, Padova 2002, 75-112.

Menn, S., Fārābī in the reception of Avicenna's metaphysics: Averroes against Avicenna on being and unity, in Bertolacci, A. and Hasse, D.N. (eds.): The Arabic, Hebrew and Latin reception of Avicenna's metaphysics, Berlin 2011, 51-96.

Nahli O., Yahyā ibn 'Adī sulla differenza fra la logica greca e la grammatica araba, in Studia graeco-arabica, 1 (2011), 47-67.

Netton, R., Al-Farabi and his school, London, New York 1992.

Neuwirth, A., Neue Materialien zur arabischen Tradition der beiden ersten MetaphysikBücher, in Die Welt des Islams, 18 (1977-8), 84-100.

Périer, A., Yahyâ ben 'Adî: un philosophe arabe chrétien du Xème siècle. Thèse pour le doctorat ès Lettres présentée à la faculté des Lettres de l'Université de Paris, Paris 1920.

Peters, F.E., Aristoteles arabus: The Oriental translations and commentaries on the Aristotelian corpus, Leiden 1968.

Platti, E., Yahyā ibn 'Adī: théologien chrétien et philosophe arabe: sa théologie de l'incarnation, Leuven 1983.

, Yahyā ibn 'Adī, philosophe et théologien, in MIDEO, 14 (1980), 167-84.

Rashed, M., On the authorship of the treatise On the harmonization of the opinions of the two sages attributed to al-Fārābī, in Arabic sciences and philosophy, 19.1 (2009), $43-82$.

-, Al-Fārābī's lost treatise On changing beings and the possibility of a demonstration of the eternity of the world, in Arabic sciences and philosophy, 18 (2008), 19-58.

Suermann, H., Habīb ibn Hidma Abū Rāița. Portrait eines miaphysitischen Theologen, in Journal of Eastern Christian studies, 58.3-4 (2006), 221-33.

Thomas, D., Tathlith, in $E I^{2}$, ed. Bearman, P. et al., Brill online 2015.

Trouillard, J., Le «Parménide» de Platon et son interprétation néoplatonicienne, Revue de philosophie et de théologie, 2 (1973), 83-100.

Turner, J.D. and Corrigan, K., Plato's Parmenides and its heritage, 2 vols., Leiden 2011.

Uluç, T. and Argon, K., Reflections on the unity/Trinity polemics in Islamic philosophy: Yahyâ ibn 'Adî and his Maqâlah fî al-tawhîd (Treatise on unity), in Journal of Middle Eastern and North African intellectual and cultural studies, 4.2 (2006), 133-61 [published in 2008].

Vallat, Ph., Farabi et l'école d'Alexandrie: des prémisses de la connaissance à la philosophie politique, Paris 2005. 
Versteegh, K., Landmark in linguistic thought: The Arabic linguistic tradition, New York 1997.

Wakelnig, E., Greek Sages on the Tawhìd. Ancient philosophy in accord with the Islamic doctrine of the oneness of God, Studia graeco-arabica 5 (2015), 205-45.

Wisnovsky, R., New philosophical texts of Yahyā ibn 'Adī: A supplement to Endress' 'Analytical inventory,' in Reisman, D. and Opwis, B. (eds.): Islamic philosophy, science, culture, and religion: Studies in honor of Dimitri Gutas, Leiden 2011, 307-26.

Zilio-Grandi, I., Il “Kitâb tahdhîb al-akhlâq” di Yahyâ Ibn 'Adî (d. 974/363): riflessioni sul tema dell'etica nel periodo abbaside, in Righi, D. (ed.): La letteratura arabo-cristiana e le scienze nel periodo abbaside (750-1250 d.C): atti del $2{ }^{\circ}$ Convegno internazionale, Pontificio Istituto Orientale 9-10 marzo 2007, Turino 2008, 273-83.

\section{Appendix}

\section{Scheme of the Treatise on [divine] unity* (tawḥ̄id) by Abū Zakariyya Yahyā ibn 'Adì ibn Hạì̄d ibn Zakariyyā al-Manțiqī al-Takrītī}

A. First divergence: on the meaning of divine uniqueness (wahdāniyya). Presentation of the four doctrines that conceive the one as:
1. the negation of multiplicity without affirmation of unity (wahda);
2. the denial of any equality with other things ("God has no equal");
3. divine unity as the unity which is the principle of numeration;
4. divine oneness comparable to the unity or oneness ascribed to all other things.

B. Second divergence: whether the Creator is one in an absolute sense, or one in a relative sense (one and many):
1. for some, the Creator is one absolutely;
2. for others, the Creator is one in one sense and multiple in another.

[Purpose of the Treatise: analysis and verification of the various beliefs with the greatest possible brevity and clarity]

[Prayer that the Treatise may succeed in its aims]

\section{Pars destruens}

Refutation of the first four doctrines 
1. The premise and the conclusion are mutually contradictory: every existent (thing) is either one or non-one (non-one=many).

2. The doctrine has two senses:

a. nothing equals the Creator in any respect (the Creator has no property or attribute - sifa - in common with other things).

a.1. nothing can be absolutely different from any other thing: everything has at least the attribute of non-equality in common with any other thing, so that everything has at least one property in common with another thing;

a.2. if the one differs from all existing things in all its attributes, then it is equal to all existing (things) and is indeed all existing (things) together (if it is not a man it is a horse, because a man is not a horse, etc., cf. Aristotle, Metaphysics $\operatorname{IV}(\Gamma) .4$ and XI(K).5-6; Physics I.2.185b2off.).

a.3. if the one differs from all existent (things) in all its attributes, then it is one thing and its opposite (it is white and non-white, black and non-black etc.), cf. Aristotle, Metaphysics IV(Г).4.1007b19-1008a25.

a.4. if the one differs from all existent (things) in all its attributes, then it is nonexistent, because what is two opposite (things) at the same time is nonexistent (= it cannot exist).

b. nothing equals the Creator in all respects (the Creator has different attributes-sifät - in common with the things in the world, but nothing coincides entirely with God):

b.1. this is the common sense of diversity attributed to all existent (things).

3. If the one is the principle of numeration:

a. Multiplicity (the many) does not exist (if only the one is the principle of numeration, then it would be impossible to add one thing to another).

b. There are many causes (if it is possible to add one thing to another, then there are many-infinite-causes).

c. This doctrine reduces the one to unity (see infra point 4; as a consequence we have, among other things, the two just introduced nonsense).

4. If divine uniqueness is comparable to the unity of all other things, the name of the one derives from that of unity; as a consequence, we are up against the problem of paronymy:

a. Both divine essence and unity are eternal: hence the essence, not being one in itself, would be manifold;

b. Essence and unity are both produced or 'brought' into being: the First Cause would then itself have a cause (divine essence would in fact be brought into being by something other than itself); 
c. Essence is eternal, while unity is produced (brought into being):

$\alpha$. Essence was initially non-one (= multiple), then one; in addition, the coming into being of unity is something produced by virtue of:

1. the essence of the cause: unity should be eternal, and this contradicts the assumption;

2. another cause, but then again:

2.i. if it is by virtue of an eternal cause: unity would be eternal, which also contradicts the assumption;

2.ii. if it is by virtue of a cause which has been produced (brought into being), then

a. either what makes it come into being is an eternal cause (but then unity would be eternal);

$b$. or what makes it come into being is a cause which in its turn is made to come into being, but then we have a regressus ad infinitum.

d. Unity is eternal, while essence is made to come into being:

$\alpha$. The First Cause would then be made to come into being;

$\beta$. Then the First Cause would be made to come into being:

i. by itself: the Cause would be at the same time existent (in fact it would be the cause) and non-existent (to the extent that it would be made to come into being; it would then be existent after its non-existence);

ii. by something other than itself: this contradicts the very definition of the First Cause; the Cause would have a cause (given the above assumption) and would not have a cause (because it is the "first" cause).

$\gamma$. Unity would be eternal as a result of the above assumption and noneternal because its essence would be non-eternal;

$\delta$. Unity would exist (given the above assumption) and be non-existent, because its essence would be non-existent.

[So far the discussion has shown that the Creator is neither one nor without equals].

II. Pars construens: the Creator is one in one sense and multiple in another sense.

A. the definition of the one, the divisions and aspects of the one and the many.

Definition of the one: it is a given existent (mawjū $\left.d^{u n} m \bar{a}\right)$ in which, to the extent that it is one, there is no diversity (ghayriyya). 
Divisions of the one:

1. Genus

2. Species

3. Relation

4. Number

a. Continuous (continuum, continuousness)

b. Definition

c. Indivisibility, and this in two ways:

$\alpha$. Indivisibility as a principle of what is divisible

i. In act

ii. In potency

a. perse

b. per accidens

$\beta$. Indivisibility as the negation of divisibility:

i. It qualifies the non-existent (e.g., hircocervus);

ii. It qualifies the existent from which nothing divisible is produced (i.e., all categories except quantity).

The aspects of the one can be grouped into three correspondences (for each correspondence there are two aspects); thus there are six aspects for each of the six meanings of the one (some examples follow), which correspond to the meanings (and aspects) of multiplicity (some examples follow):

1. The one as a genus $\neq$ many genera
a. In potency $\neq$ in potency
b. In act $\neq$ in act
c. In subject $\neq$ multiple subject
d. In its definition
e. perse
f. per accidens

2. The one as a species $\neq$ many species
a. In potency
b. In act
c. In subject
d. In its definition
e. perse
f. per accidens 
3. The one as a relation $\neq$ many relations
a. In potency
b. In act
c. In subject
d. In its definition
e. perse
f. per accidens

4. Continuous [continuum] $\neq$ many continuous things (e.g., many lines)
a. In potency
b. In act
c. In subject
d. In its definition
e. perse
f. per accidens

5. Definition $\neq$ many different definitions or descriptions of [the same subject]
a. In potency
b. In act
c. In subject
d. In its definition
e. perse
f. per accidens

6. Indivisibility (as a principle of divisibility) $\neq$ multiple indivisibilities (which produce that which is divisible, such as numbers or lines)
a. In potency
b. In act
c. In subject
d. In its definition
e. perse
f. per accidens

- The correspondent of the one in the subject is multiple subjects, i.e., individuals [the subject is here considered a division of the one and the many, and not an aspect].

- Explanation of why [the manifold which is indivisible non being the principle of the divisible] is not taken into consideration. 
Examples of the divisions of the one:

1. One in a genus: a living being;

2. One in a species: man;

3. One in a relation: source — stream/heart—arteries;

4. One as a continuum: a sphere, a line, a flat surface;

5. One in a definition: man ("rational mortal animal");

6. One indivisible

a. Principle of the divisible

$\alpha$. Units (principle of what is divisible in act: numbers [numeration]);

$\beta$. A point ([principle of what is divisible in potency in itself: a line);

$\gamma$. An instant ([principle of what is divisible in potency: time, which is divisible by virtue of the continuity of movement);

$\delta$. Principle of motion (principle) of what is divisible in potency: motion (which is divisible only because it is continuous by virtue of the continuity of the body that is in motion);

b. Absolute denial of the divisible:

$\alpha$. A subject that does not exist (hircocervus);

$\beta$. An existing subject from which nothing divisible derives, that is to say all categories (except quantity).

Examples of the aspects of the one:

1. One in act: one line;

2. One in potency: water and wine;

3. One in subject: the sun (or, from another perspective, Zayd);

4. One in definition: one man;

5. One in essence: one body, one surface, one line;

6. One per accidens: one army, one troop, one flock, all black things together (e.g., a black man, ebony, tar, a crow).

Examples of the divisions of the many:

1. Many in a genus: animal, plant, substance, quality;

2. Many in a species: man, horse, bull;

3. Many in a relation: different relations: two to one/three to one;

4. Multiplicity in a continuum: multiple lines;

5. Multiplicity in a definition: the definition of man, a horse, a bull or any one of the definitions scil. descriptions) of Socrates (different definitions of the same subject);

6. Multiple in subject: the different subjects in the definition of man, horse, etc.

7. Indivisible multiple:

a. A number (which has parts in act);

b. A line (which has parts in potency). 
Examples of aspects of the manifold (or multiple):

1. Manifold in act: units and lines;

2. Manifold in potency: a line;

3. Manifold in subject:

a. per accidens: the different members of the human species;

b. In essence: the subjects of the different species (e.g., science and white);

4. Manifold in its definition: man, horse, bull or any one of the definitions (scil. descriptions) of Socrates;

5. Many in essence: an army and troops;

6. Many per accidens: Zayd (has many accidents but one subject).

III. Refutation of the doctrine that God is absolutely one or absolutely manifold: the refutation uses arguments that reveal how absolute unity and/or multiplicity are inconceivable (e.g., [the derivative name] of the one is also applied to the many; unity is revealed by the many in various aspects); the Aristotelian assumption according to which the one is the principle of numeration as well as the opposition between the one and the many as the opposition between the measure and the measurable are used instrumentally by Yahyā ibn 'Adī.

IV. The meaning of the fact that the Creator is one in one aspect and multiple in another is clarified (Which divisions and which aspects of the one and the many are attributed to the First Cause is established).

A.1. The Cause of causes:

1. Is not one that belongs to a genus (it would then have been caused: the genus exists because of its members: therefore, contradictorily, the First Cause would be caused, as a genus, and not caused, as First Cause);

2. Is not one that belongs to a species (it would then have been caused: the species exists because of its members; therefore, contradictorily, it would be caused, as a species, and not caused, as First Cause);

3. Is not one that is part of a relation (relation is an accident);

4. Is not one like a continuum (it is not a body—cf. Aristotle, Physics VIII-and cannot have accidents);

5. Is not one like something indivisible;

a. Either in the sense of a simple negation of divisibility (the Cause as one would not then have the specific meaning of unity);

b. Or in the sense of the indivisible which is the principle of the divisible (the cause is not a unit, or a point: these things are all in one subject and the Cause would then be a caused effect):

6. Is one in its definition (its defining discourse is one). 
A.2. The Cause of causes:

1. Is not one in potency (it would be caused): it is one in act;

2. Is not one per accidens (it would consist of a group of units): it is one in essence;

3. Is one in subject because it is one in its definition.

B.1. The same arguments applied to unity are valid for multiplicity. The Cause:

1. Is not manifold in a genus;

2. Is not manifold in a species;

3. Is not many in a relation;

4. Is not manifold like a continuum (as many continuous things);

5. Is not manifold like something divisible;

6. Is manifold in its definition.

B.2. Analysis and refutation of the objection of those who find a contradiction here: the definition itself is composite: therefore what is one in its definition is multiple at the same time.

B.3. Aspects in which the Cause is manifold:

1. The Cause is not many in potency (it would then have been caused), but in act;

2. The Cause is manifold in essence because it is manifold in its definition;

3. The Cause is multiple in its definition (as has been demonstrated).

C. On the conceptual notes (ma'ānī) that describe the First Cause:

C.a. one thing is:

1. Manifest in both substance and effect (the effect is also the set of consequents of the thing);

2. Hidden in both substance and effect;

3. Hidden in substance, but manifest as regards effect;

4. Hidden as regards effect, but manifest in substance.

So a thing can be:

1. Unknowable;

2. $\quad$ Evident (e.g., fire);

3. Knowable through experience and inference (e.g., hellebore);

4. Knowable by inference from effect (e.g., the soul, intelligence, God the Creator).

\section{Generosity, Power, Wisdom}

It is evident that God, the Creator, can be known because of His effects (creatures).

Therefore it is said that He manifests, first, generosity (jūd): things are, after not having been, they imply a Cause that brings them into being. This Cause can cause: 
1. By essence: then its act follows immediately and simultaneously (according to the naturalistic and emanative images; e.g., light, fire);

2. Because of something other than its essence.

\section{However:}

1. The Cause cannot cause essentially, because things-whether universal or particular-are, after not having been. In fact, individuals exist after having been non-existent, and general or universal things derive from individuals; therefore they too are, after they have not been.

2. The Cause, therefore, causes because of a choice (not because of its essence).

The choice can be:

i. Due to compulsion, but the First Cause cannot be forced, because:

1. If it were forced, the Cause would be caused (it would be the instrument of what forces it);

2. It would be caused, by means of coercion, and not caused because it is the First Cause;

3. That which compelled it would be at the same time existent and nonexistent: it would be existent (because it would force the Cause); it would also be non-existent (the Cause is what brings into existence after being nonexistent what is other than itself).

ii. Due to generosity.

The Cause, therefore, causes because it chooses to, because of generosity.

Of God the Creator it is said that He possesses power (qudra).

The Cause has the power to do and to stop or interrupt what it does. Effects, whether they are individual or universal, exist after not being existent and if the Cause would not stop to make them exist, there would be a contradiction: some effects would be known by experience to be existent after being non-existent-like individuals-and other effects which would be known by demonstration to be existent after being nonexistent - like universals — and both of them would be, by assumption, continuously existent.

Finally, of God the Creator it is said that He manifests wisdom (hikma): all created things show signs of excellence and conformity with the purpose for which they were created (as evidenced by the discourses of the Ancients, and as revealed by sensory experience): these signs can be explained only by virtue of the intention of a wise Agent. 
The three attributes - which are the effects - are neither more nor less of what they are, and what is meant by each of them is different from what is understood by the others.

Who are the readers of the Treatise?

Appendix: A doubt about the possibility of being one and other than one (see the Parmenides of Plato). 